[Type here]

\title{
From Global Workers to Local Entrepreneurs: Former Global Factory Workers in Rural
}

\section{Sri Lanka}

"When I went to the Free Trade Zone [FTZ] I only had the clothes on my back. When I left I had money, jewelry, friends, fearlessness.... Now I have my own 'factory' and I subcontract for the same factory I used to work for. Venura sir even calls me his 'best small factory owner."' So said Hasini while showing me her workshop that was thatched with coconut fronds and was built in between her kitchen and the home's boundary walls. Although it was a temporary hut, it contained Hasini's most prized possessions-four industrial sewing machines she had purchased using savings from her FTZ work. These machines made a tangible difference between her time as a global factory worker and her life as a local entrepreneur, or in her words "village factory owner."

Merely owning sewing machines is not enough to become an entrepreneur, because one needed good market connections in Colombo and within the FTZ to ensure they received subcontracting orders. Hasini and many former workers also evidenced that monetary success achieved via subcontracting was just one part of becoming socially successful in their respective villages; because overall success required combining monetary capital with astute local cultural knowledge to manipulate extant social and symbolic capital.

This article explores the ways in which former garment factory workers become successful local entrepreneurs and subsequently initiate crucial changes in village social and economic spaces, including changes in gender norms. I contend that their experience at the FTZ, which generates savings (besides allowing them to develop a set of skills, connections, and know-how), and their ability to manipulate this monetary capital by combining it with varied 
[Type here]

forms of capital available locally is what makes most former workers economically and socially successful within village contexts. While acknowledging that global assembly line work is part of contemporary global capitalist hierarchies structured to exploit and discard gendered third world labor, this article demonstrates how FTZ work, quite unexpectedly, initiate a process of social and gender norm changes in rural Sri Lanka.

Drawing on ethnographic fieldwork conducted over 8 years I explore how former FTZ workers become local entrepreneurs and community leaders while simultaneously initiating gradual changes in rural social hierarchies and gender norms. These entrepreneurial activities, more often than not, link former workers to the cascading system of subcontracting that characterize global production networks. Sharad Chari, ${ }^{1}$ Alessandra Mezzadri, ${ }^{2}$ and De Neve, ${ }^{3}$ all focusing on subcontracting workshop owners located around large urban factories in India, view such entrepreneurs as part of the cascading system of outsourcing that further exploit workers and intensifies the precariousness of neoliberal livelihoods. These studies focus on male entrepreneurs who operate workshops in cities. By focusing on former FTZ workers, who operate workshops from their marital homes in Sri Lanka's villages, this article instead examines an even lower rung of the global production networks; for these former FTZ workers subcontract from local subcontractors, the likes of those Chari and DeNeve discussed. By going beyond the global factory, the article further analyzes how former workers' engagement with global production networks via home workshops impact village communities differently than urban subcontracting operations run by men.

While demonstrating how working in FTZs introduces Sri Lankan women to neoliberal ways of fashioning selves and how their village entrepreneurial activities initiate negotiations in kinship and domestic arrangements and community relations, the article highlights how varied 
[Type here]

manifestations of neoliberal attitudes within local contexts result in new articulations of what it is to be an entrepreneur as well as a good woman. Most scholarship on female global assembly line workers do not follow them back to their villages after they leave the factories. Thus an understanding of how former workers may use their new knowledges and savings to negotiate village lives is a lacuna in the literature on neoliberalism's effects on people and communities. By focusing on former FTZ workers' village entrepreneurial activities, I show the particular ways in which these women manipulate FTZ monetary and social capital, together with local social and cultural capital, to initiate a gradual transformation in local gender norms and village hierarchies. In doing so, I demonstrate the long-term impact women's temporary employment in global factories has on individuals, families, and communities.

\section{The Free Trade Zone and Changing Selves}

The structural adjustment policies the World Bank initiated for debt-ridden developing countries saw western investors and multi national corporations taking advantage of tariff free export oriented production zones to establish factories that produced myriad goods, especially garments and electronics. Utilizing third world labor at very low salaries, these corporations strive to minimize production costs to the lowest possible. The countries that stood out in hosting global factories included Vietnam, Thailand, Indonesia, Bangladesh, Mexico, Honduras, and China. While manufacturing jobs in these global assembly lines provided much needed wages for unemployed youth, reports of labor and human rights abuses within factories raised concerns among global consumers. The global assembly lines in fact are gendered in its structure as the companies mainly hired women. This tendency was based on patriarchal stereotypes of women being nimble fingered, docile and supplementary earners--as opposed to men who get considered the family's main bread winners. Amidst reports of labor exploitation, bad work conditions, and industrial disasters global factories in many non-western societies continue to operate with varied 
[Type here]

levels of compliance to international labor codes. A crucial piece of knowledge missing from these narratives is what happens to female workers after they leave these precarious industrial jobs at export processing zones. Taking an intimate look at former global workers who have returned to their villages in Sri Lanka, this paper is trying to fill this gap.

The first Sri Lankan FTZ was established in 1978 in Katunayake, a town about 35 kilometers from Colombo and home to the island's only international airport, after a new government began pursuing structural adjustment programs. Unemployed rural women were expected to fill the newly created assembly line jobs, characterized by rigorous schedules, poor work conditions, and minimal wages, since it was assumed that, having no other options and being supplementary wage earners, these women would accept employment under any conditions.

As in other transnational factories around the world, Katunayake factories demand maximum output for minimal wages in exploitative working conditions and practice a distinctively late capitalist form of gendered working relations. ${ }^{4}$ Even today more than 35000 rural women from economically and socially marginalized groups work as machine operators in the FTZ's 92 factories while about 40,000 more work for subcontracting factories located around the zone (Sri Lanka Board of Investment, 2016). Most are unmarried, young, and relatively well educated. In 2015, just over 80 percent had passed the General Certificate of Education (Ordinary Level) exam. ${ }^{5}$

Most workers migrate from economically stagnant areas in North Central and Southern Province. As of July 2019, the basic salary of a FTZ worker was Rs. 13,000 (about US\$ 75) per month, but women can earn about Rs. 20,000 by working overtime and forgoing allotted annual leave. There are very few state or factory-run hostel facilities for these women. The locals have 
[Type here]

therefore built rows of rooms for rent, resulting in extremely poor living conditions. The problems associated with boarding houses exacerbate the stress stemming from arduous working conditions and low salaries to make life in the FTZ difficult. ${ }^{6}$

Workers' status as young women living alone receives much public and media attention. Frequent media accounts of widespread premarital sex, rape, prostitution, abortion, and infanticide portray the FTZ workers as victims of labor and sexual exploitation and their own loose morals. The stigma attached to migrating for FTZ work results from constructed notions of the ideal woman being an obedient woman who is sheltered among family until marriage.

Although these rigid gender norms were constructed as part of the anti-colonial movement in late $19^{\text {th }}$ and early $20^{\text {th }}$ centuries, women continue to be evaluated as per such standards.

Consequently, migrating to the city and living away from their families in a stigmatized space affect their reputations and lowers their value when it comes time to contract marriages. ${ }^{7}$

Although the difficulties associated with FTZ work seem to outweigh gains, a stagnant agricultural economy, lack of alternative employment, and quest for urban lifestyles appear to motivate women to migrate. By working in the FTZ and living with other young women in an urban area, rural women experience social, cultural, emotional, and cognitive changes. They start to enjoy relative freedom of movement and increased decision-making powers. They acquire global knowledge flows on reproductive, labor, and human rights, and the intense socialization process in factories and boarding houses encourages them to dress, behave, think, and desire in new ways. Furthermore, they develop forms of political and feminist consciousness and absorb the particular form of neoliberal narratives that circulate within the FTZ area. Feminism here is understood in a post modern sense as feminisms-where women struggle for gender equality in locally meaningful ways. According to this understanding, 
[Type here]

women will not wholly buy into western hegemonic feminist notions of individual autonomy and full agency, but rather strive for agency and empowerment within meaningful and beneficial local cultural frameworks.

While negotiating difficult lives in transnational factories, they develop friendships and mentoring relationships with people in the area, NGO staff members and even local and foreign aid workers and researchers. ${ }^{8}$ Most workers eagerly attend dancing, English speaking, beauty culture, and computer classes offered by NGOs. Several NGOs in the area also run educational workshops for workers that partly deal with how to develop income-generating activities once they return to villages. Through these classes, and through their mentors (boarding owners, NGO officials, factory officials), women meet small subcontractors in the area and learn about how one could generate income in the global economy. Most NGO workshops include sessions on entrepreneurship, and at one workshop I attended two speakers discussed how to set up subcontracting workshops in villages and how to get orders from large FTZ companies. Some FTZ factories also provide self-employment training. For instance, Mas Holdings, a major company with several factories at Katunayake and elsewhere, has a program, titled 'Women Go Beyond', with the aim of providing their workers with multilateral skills like bag and shoe making, and bridal dressing, etc. They also train workers in personal finance management. ${ }^{9}$

Most workers were appreciative of these educational opportunities and felt that the NGOs and factories should be commended for having their best interest at heart. This was not surprising considering that some of the training and networking was done within programs that were organized under company corporate social responsibility (CSR) agendas. Workshops were also sponsored by local NGOs with connections to prestigious organizations such as UNICEF, UNIFEM, ILO and the Canadian International Development Agency (CIDA). 
[Type here]

Workers usually are petrified by the thought of having to return to their villages when their labor clocks run out in five to six years. Not wanting to be confined to living the life of a village wife, most prepare themselves by enthusiastically participating in these workshops. The knowledges acquired and networks created at training workshops help them connect with the gig economy once back in the villages. Gig economies are characterized by independent contractors who take up outsourced work that are normally done by the traditional work force. ${ }^{10}$ These outsourced subcontracts are unpredictable yet plentiful and provide opportunities for nontraditional workers (i.e. those who are part time and work out of the home). Former FTZ workers, thanks to the knowledges acquired while working in factories, are well positioned to take advantage of such opportunities. In fact, some workers subcontract for small urban subcontractors while at FTZ factories and continue doing so at their marital homes after leaving the FTZ. Factories also recruit former workers, based on the skill they displayed while being part of the regular work force.

While microcredit provided by state and non-state actors have gotten village women into entrepreneurial activities, the results have been mostly disappointing. ${ }^{11}$ However, former FTZ workers' knowledge, social networks, and savings combined with microcredit allow them to plan, set up, and develop entrepreneurial activities in ways their non-migrant peers are not equipped to do. The so-called "FTZ dowry" turns out to be a major catalyst for former workers in this regard. When one produces a marriage certificate within three months after leaving, workers can obtain both their accumulated Employee Provident Fund (EPF) and Employee Trust Fund (ETF) money together with a five-year gratuity payment from the factory. Workers refer to this lump sum as the "FTZ dowry." Unlike the dowry a bride's parents give the groom's parents, this gets deposited in a bank account in the worker's name. The label "FTZ" directly connects 
[Type here]

the money to the women's labor, and their spouses and affine, for the most part, allow them to use the money for the family's economic advancement in ways the workers find appropriate. Although most workers have used varied sums of the dowry on family events and emergencies as gestures of good will, relatives of all 37 women I interviewed for this study noted, in some way, that the FTZ dowry was meant for the women to start a business and that families should not make demands on it unless doing so was absolutely necessary. It is this FTZ monetary capital that women use creatively, together with other forms of capital, to stretch normative boundaries and activate social change.

\section{Methods}

I have since 2003 investigated how former FTZ workers integrate back into their villages as prospective brides, new wives, and young mothers. I have focused on former workers in such roles as they usually leave work to get married. During participant observations over 18 years among FTZ workers (mainly within the Katunayake FTZ and to a lesser extent the Biyagama FTZ) I only met one lesbian and four single women. Workers speculated about five other women as 'possible lesbians.' This does not demonstrate that there are no homosexual desires or lesbians among the worker population. Rather, it demonstrates how such desires are not allowed to flourish within the heteronormative Sri Lankan society, making it hard for the workers to identify desires or claim such identities.

The research for this paper was conducted over multiple visits to women's homes starting in the summer of 2005. From then onwards until 2015, but excepting 2007, I stayed in workers' village homes every summer. Visits also took place during the winters of 2007 and 2008. Altogether, I stayed in 37 workers' village homes to examine how these former workers negotiate living with the new sense of self and political consciousness acquired in the FTZ. The 
[Type here]

duration of the visits varied, ranging from two weeks to three days. I revisited all 37 homes, and these repeat visits ranged from three to six occasions. In addition to the hours spent interviewing former workers in these villages, I interviewed their relatives, in-laws, and neighbors. I also participated in their gendered social activities and expressive practices (storytelling, joking, singing), and followed them as they engaged in village social and political activities.

As part of my doctoral dissertation research, I worked at a Katunayake FTZ factory and lived with about 60 factory workers in a boarding house for 12 months, and this is when I first got to know most of these 37 workers. My particular positioning as a researcher who shared their ethnicity, religion, and gender while being fluent in the local language immensely helped me become friends with these global workers. The friendship with these women and others in the FTZ area continued post-dissertation research via letters and telephone and during my frequent visits to Sri Lanka. I have also visited them in their village homes following their invitations and the current research began taking shape after I have started seeing particular patterns over few years. These women, therefore, were not selected according to a recognized sampling method.

It is legitimate to ask if only the workers who had something to show invited me to their homes. The fact is that these women initially had little to flaunt. The invitations were based on friendship coupled perhaps with a desire, on the part of some, to show off to in-laws a friend who worked in the United States. The fact also is that it took me awhile to see how these former FTZ workers manipulated the varied sources of capital at their disposal. I readily acknowledge that the study of this particular group of former workers would produce only an account particular to the group, but it is important to note the advantages of studying a group of women who are willing and inviting. These women trusted me enough to recount details about their sexual 
[Type here]

experiences, share erotic jokes and giggle over whispered secrets. While the things we had in common—ethnicity, religion, and language—benefitted my research, the cultural capital I embodied as an educated, middle class woman complicated matters. The inequality notwithstanding, these relationships were/are warm and affectionate, and helped ease me into research within village settings.

I formally interviewed 37 workers and their spouses and/or in-laws. Two to three nonmigrant women in each village were also formally interviewed. I interviewed the Grama Niladari (Village Officer) of all 37 villages, 16 chief monks and 49 village dignitaries. Only a few interviewees showed reluctance to being taped. In addition, I participated in women's story telling sessions, organized trips to scenic places, and attended meetings of village organizations and festivals. I was given permission to tape and video record and photograph all these activities. Videotaping was minimally used to allow for a smooth unfolding of social interactions. In each of the villages, I had informal conversations with other former FTZ workers whom I met while visiting organizational meetings, temples and ceremonies. Pseudonyms have been used throughout to protect privacy. Village names are withheld to further ensure that none of the women or their relatives are identifiable.

\section{Exceptions, Flows and Reconfigurations}

Neoliberalism represents a set of political economic practices that hold "human well-being can best be advanced by liberating individual entrepreneurial freedoms," 12 within an environment of strong free market policies and free trade. Neoliberalism also works as a form of governmentality by instilling norms of individual selves as autonomous, self-directing, agents. ${ }^{13}$ Thus a neoliberal subject is an individual who relies on cost-benefit analysis, market based 
[Type here]

principles and embody the spirit of entrepreneurship. As Gershon ${ }^{14}$ notes, such individuals are disciplined, risk-taking and bent on optimizing skills, and in short represents a "company of one." Thus some theorists define neoliberalism as a mode of governing through freedom that gives individuals choice and the responsibility of navigating and enhancing their own social worlds.

Although some theorists suggest that neoliberalism has become hegemonic in today's western world, ${ }^{15}$ Ong holds that neoliberalism, rather than being the predominant mode of thinking and practice, is an exception to the politics as usual, especially in Asia. According to Ong, in countries like China, Malaysia, and Hong Kong, there are designated zones or dedicated areas that are neoliberal havens while societies remain largely repressive and run as welfare states. ${ }^{16}$ Similarly, Sri Lanka's former FTZ workers, having returned from an area where market relations and neoliberal ethos of autonomous, agentive individual flourish, find that they now have to navigate a different set of prescriptions. Rather than completely giving up on neoliberal ethos, they start a delicate process of tradeoffs that then reconfigure and rearticulate both neoliberal ethos and local gender norms, family and kinship arrangements and social hierarchies. Thus while neoliberalism manifest in Sri Lanka in the first instance as an exception, its attendant narratives and discourses escape those confines and travel to different corners of the country via former global factory workers. The villages the former workers return to are more or less differently positioned in their experiences of national and colonial history, cultural practices and socio-economic standing. Thus former workers have to combine neoliberal entrepreneurial sensibilities, skills and resources acquired in the FTZ with local resources, such as affinal social networks and cultural knowledge, to ignite economic success. In short, they have to manipulate varied forms of capital at a given moment to best suit the context. This also includes performing 
[Type here]

rituals of social conformity to repair their damaged reputations, which then leads to the support of affinal kin and the community. The latter is a must for a woman, no matter how skilled and thoroughly embodying neoliberal sensibilities, to succeed economically. Thus while neoliberal ethos and practices escape exceptional spaces and reach remote corners of countries like Sri Lanka, they confront deeply held local cultural understandings and take root in rural areas only in locally specific ways.

Mills ${ }^{17}$ asserts that the gendered moral narratives stemming from new patterns of global production in Asia reveal how local ideological support sustains neoliberal models of development and governance. Invoking both Lynch $^{18}$ and Hewamanne, ${ }^{19}$ Mills further elaborates how narratives and images of female immorality connected with global production in Sri Lanka to initiate varied moral and material demands that marginalized and gendered groups must carefully navigate daily. Freeman ${ }^{20}$ also discusses how upwardly mobile middle class entrepreneurs must walk the tight rope of respectability while engaging with a flexible economy. Women who may get recognized for hard work and creativity can suffer loss of respectability, and Freeman focused on symbolic tradeoffs people navigate when availing themselves of flexible economic opportunities. Similarly, Sri Lankan women must also maintain a delicate balance between pursuing income generating activities formerly reserved for men while performing culturally expected "good women" roles. This balancing act reshapes neoliberal ethos at the same time as it initiates changes in the very norms that necessitates the balancing. Thus how former workers negotiate social economic life in their villages may, in the long run, help erode the gendered moral narratives that support the exploitative global production arrangements in Sri Lanka. 
[Type here]

Gibson-Graham advocates for reading economic activities for 'difference rather than dominance,' so as not to take neoliberalism as a dominant, totalizing regime but look for its failures and weaknesses that give credence to alternatives. ${ }^{21}$ While what I describe below does not evidence women creating alternative economic paths, it does highlight the weaknesses of neoliberalism as a regulative technology even as it shows the enduring strengths of existing cultural expectations. While most former workers are tightly connected with market based economies through their entrepreneurial activities and astutely manipulate forms of capital, they do that to the extent that extant cultural norms allow. It is precisely this restraint that allows for the simultaneous loosening of restrictions on women's mobility. The ways in which former workers negotiate economic activities and social relationships in villages necessitates reassessing the dominant narratives of how neoliberalism is establishing itself in varied contexts.

\section{Global Factory Workers Coming Home}

Neoliberalism also means a redefinition of what it is to be a worker. According to Foucault, the worker has become "human capital" because any activity that generates salary or income, gives satisfaction, increases one's status within family and community, and promotes travel and civic engagements are investments in human capital. ${ }^{22}$ The flexibilization of capital and labor in turn promotes the 'gig economy,' and neoliberal subjects invest in themselves to engage in this economy by becoming self-reliant, risk taking entrepreneurs. This article focuses on the question whether former workers have become neoliberal subjects, and are now the catalysts incorporating villages in capitalist market relations, or whether there is space for an alternative reading of how they utilize forms of capital to engage with the socio-economic worlds 
[Type here]

of rural Sri Lanka. I highlight the particular entrepreneurial trajectories of several village women to explore how FTZ work is connected to social changes taking place in rural Sri Lanka.

\section{Hasini: Factory Owner Daughter in Law}

"I would never have been able to achieve what I did without mom and dad's support," Hasini told me while pointing to her parents-in-law who were seated a few feet away. "Amma sews with me, makes tea for everybody at the workshop, and most importantly keeps an eye on the baby and the older one [child]. Thaththa takes cut pieces to village women's houses on his bicycle, and sometimes collects the finished pieces too," Hasini further elaborated. Although she remained very appreciative of her parents-in-law during discussions throughout the years, she also angrily noted that her mother-in-law kept a vigilant eye on her in the beginning because she was suspicious of her moral character as a former FTZ worker. Despite harboring "fire in the belly" or aspirational capital ${ }^{23}$ needed for entrepreneurship, Hasini had to reign in her enthusiasm when first married.

"I knew that I needed to win the mother-in-law over. Both Asoka and Namali advised me to keep my head down, not to show off too much knowledge, not do flashy styles, and show lots of deference to the parents-in-law," Hasini said. This was important to her as her former factory (a large subcontracting factory just outside the FTZ) asked her to consider setting up a village workshop to take up subcontracting orders from them. They have promised that if she can start work with two machines, they would later help her buy two more.

Just like many other former workers, Hasini also found that surveillance mechanisms are stricter for newly married women, and more intense in the case of former workers due to the FTZ associated stigma. Cultural expectations and surveillance cause former workers like Hasini, who 
[Type here]

developed an intense oppositional consciousness during their time in the FTZ, to discipline their bodies, speech, and mannerisms. This apparent conformity (or deployment of local cultural knowledge) eventually opens up avenues for economic and social empowerment.

Hasini used her FTZ dowry money to buy one machine, which she brought to the marital home. But she needed an actual workshop, however makeshift, to attract subcontracts from the factory. In her own words, she went into "operation winning in-laws' support," mode, which included exaggerated forms of social conformity like kneeling down and paying respect to all elders, being diligent with household activities, cooking, cleaning, and quickly attending to her husband and in-laws' needs. She also used some of her money to buy a telephone and flat screen TV and to take her mother in law to a specialist doctor in Colombo.

"I always talk to the relatives about bad behaving FTZ girls and berate them for giving a bad name to the good girls like us who just wanted to work hard and help their families," Hasini laughingly said. All this helped her win her in laws' support to build a small hut and buy two more machines within two years of marriage. As the subcontracting work started bringing in money that in turn allowed her to purchase luxury goods and finance an addition to the house, her mother-in law, co-sisters and some neighboring women began taking over her domestic responsibilities, which allowed Hasini more time to manage her "small factory." Both Hasini and her mother-in-law daily negotiated the expectations of kinship relations, existing divisions of labor, and new economic demands. When Hasini began preparing meals, her female in-laws or a neighboring woman would often insist on doing the work instead. When asked why she is not expected to cook and clean as other young, married women, Hasini laughingly said, "it is because I am a factory owner." Then in a more serious tone she said, "this factory changed my life....I employ village women and my co-sisters. They all appreciate the opportunity to work 
[Type here]

from home while managing family responsibilities. It is with their support that I managed to be elected chairperson of the village women's society and the Sarvodaya (NGO) branch. I donate generously to temple activities. When I go to the temple, the chief monk summons me to his residence to discuss temple matters. So obviously, my in-laws feel the need to help me."

When asked how her husband feels about her entrepreneurial and social success, Hasini again laughingly said, "oh, he likes it....the first thing I bought with my profits was a motorcycle," and then later added that she knew her success might make him jealous and cause him to restrict the space she was slowly carving out. "We have to use all 64 vices to not make them feel jealous. They are like children. If you keep saying they are the household head and leader of the family, they just let you lead the family the way you want to," Hasini said. She also said that financial and social success also improved her marital relations. "Those days if he wanted to have sex, he just assumed I would go along. Now he is concerned about my energy level, sleepiness, and next day's schedule, etc. I know that subcontracting can get very stressful as we have targets to meet, but I wouldn't forego this for anything in the world. This factory gave me life, dignity, and a say in what matters."

Only three women out of 37 listed improvements in marital relations as one of the positive outcomes of their village entrepreneurial activities, but all of them in different ways noted how entrepreneurial success allowed them more status, and decision making powers within their families and communities. Their achievements, at least in the beginning, seemed to require "double duty" as they had to be extra-diligent in household chores while doing part time entrepreneurial work. However, the more a woman performs conformity, and evidences allegiance to her roles as cook and cleaner, the more help she receives from in-laws and neighbors. Hasini is a perfect example of how a skillful former worker intricately combines 
[Type here]

different forms of capital—monetary, social and cultural—to create even more social capital that leads to financial success and changing attitudes.

Mayuri: Manipulating and Multiplying Capital

Vijelatha, mother-in-law of Mayuri, somewhat sheepishly told me how she objected to her son's marriage to a former garment factory worker. "She had a good dowry, so I agreed to the marriage in the beginning, but then rumors about her former boyfriend and her not being a virgin reached us, and I cancelled the wedding plans. The young couple nevertheless got married and moved into a mud hut he built on an abandoned plot. Mayuri won her mother-in-law's heart by a show of fortitude and obedience. After recounting how Mayuri's humility made the chief monk and neighbors pressured her, Vijelatha said, "finally, I forgave them and asked them to come and live in the house."

Later, Mayuri explained why she went through such a show of humility. "We could never have bought land and built a house with our income. People said your mother-in-law will accept you when you have a baby, but I needed a house and a business going before having babies. Now they have given us land and all the wood for the house too will come from the land. In any case, people need family," she added, touching her pregnant belly. Vijelatha once told me that Mayuri is like a goddess for the house. "She is always smiling and humming songs even while cooking. Does all the work around here and then runs to the temple and the school for NGO work. She is the bank manager there, and she just obtained a loan to start a business." Vijelatha praised Mayuri's entrepreneurial activities and traditional duties in the same breath, evidencing how market-based economies have penetrated the village psyche, albeit without altogether altering conventional expectations. 
[Type here]

Mayuri also travelled to the NGO headquarters in Colombo for bi-monthly meetings and once attended a workshop at a mountain resort. A framed photograph of her speaking in front of a microphone was on the top of the family's china cabinet. She took micro credit loans from several organizations ${ }^{24}$ in the village and region, combined her own savings and invested in three income-generating activities. She used her FTZ savings to pay off her loan in installments, an option not available to non-migrant women. One of her most lucrative economic activities was re-loaning her micro credit loans to other women who have defaulted on their payments. She interpreted this as a social service to women who have no other reliable low interest options to get loans. Although touted as a way for village women to become entrepreneurs, alternative readings of micro credit have shown how they lead to new forms of oppression and hierarchies. ${ }^{25}$ Several studies, including my own forthcoming work, show how most village women felt as if they have fallen from the "stove to the fire" by taking high interest micro credit loans given by private financial institutions. Several works evidence how defaulted loans and harassment by creditors lead to domestic violence in Sri Lanka ${ }^{26}$ and elsewhere in South Asia. ${ }^{27}$. Mayuri's micro credit re-lending business is one manifestation of the adverse forms micro credit can take in different contexts. At the same time, it shows how former workers are particularly equipped to use and abuse micro credit opportunities for their own economic success.

In 2012, I was thrilled to observe Mayuri leading a meeting while breastfeeding her first baby. She only missed two meetings during her pregnancy and started bringing the baby to meetings when he was about eight weeks old. Her parents-in-law fully supported this move and helped squash some minor objections from the community. In August 2015, she continued to lead different village forums with her five-month-old daughter at her breast. While taking babies to work is not a new phenomenon, especially for female agricultural laborers, seeing a woman 
[Type here]

who did not have to work for a living doing so, especially while doing voluntary social service, was something new for many villagers. Here Vijelatha's support for Mayuri to be in the public space, when the public expected her to be tightly tethered to the domestic space with her baby, was crucial.

Vijelatha's transition from a stereotypical mean mother-in-law to one who is supportive of Mayuri's economic, social and political activities was directly related to Mayuri continuing to perform good, obedient daughter-in-law traits. The more Mayuri adhered to expected behavior, the more support she received to step outside the mold, which evidences how the old and new engage in an intertwined process that creates new spaces. Mayuri's entrepreneurial aspirations would have failed without her in-laws' support and their village social capital. Gaining approval to pursue new activities depended on how skillfully the younger woman maneuvered local cultural expectations and shows how affective and other forms of labor are tightly intertwined in everyday life.

Husbands usually allowed their mothers and wives to negotiate household responsibilities and mostly remained detached from how things were run. In almost all cases, fathers in law had affectionate and supportive relationships with their daughters in law. However, all the women confided that the support of husbands and fathers in law depended on their relationships with the mother-in-law; hence it was crucial that one adhered to (at least in words) traditional expectations when trying to carve out a position in village public spaces. Women like Mayuri navigate a reality wherein, on the one hand, market-based mores and practices are celebrated while, on the other hand, conventional prescriptions for proper behavior still shape their social status. The chief monk of her village temple spoke of Mayuri in glowing terms in 2017, noting her hard work, courage, and humility. "Mayuri is a great role model for any person, man or 
[Type here]

woman, young or old," he said. Mayuri was honored, but was also cognizant that the praise was directly related not just to her financial success and social service, but also to how she conducts herself in line with conventional expectations.

Alessandra Mezzadri and Majumdar ${ }^{28}$ notes how most Indian garment workers who left factory work are now part of the poor, laboring masses now in urban areas who engage in sporadic physical labor for survival. Obviously, the contexts are different. But also some policy differences, such as the FTZ dowry help contribute to the positive outcomes among Sri Lanka's former workers. While, according to Mezzadri and Majumdar, Indian female workers leave factories with upto Indian rupees 50,000 in debt, Sri Lankan workers get a lump sum of combined EPF, ETF and factory gratuity. ${ }^{29}$ How they use it depend on several crucial factors but the financial outlook of their post-FTZ lives were strong allowing women like Mayuri to become local entrepreneurs and civic leaders.

\section{Non Migrant Village Women}

The non-migrant women I interviewed were married to military men, businesspersons, teachers, or other minor city workers, who generally owned small plots of arable land. Their work provided just enough to eke out a respectable living without falling into substantial debt. Many non-migrant women wanted to contribute to the family economy and expressed varying levels of desire to engage in meaningful economic activities. They, however, find that it is not easy to start sustainable income-generating ventures without the kind of educational opportunities and networking that Hasini and Mayuri were exposed to within the FTZ. The only activities that they could think of, and, in some cases tried and failed, were opening a small 
[Type here]

grocery store, preschool, or beauty salon; only to quickly realize that a village does not need more than two or three stores, preschools, or beauticians.

The economic success of many former workers and their enhanced performance of domestic duties due to newly acquired electric appliances have initiated a counter-narrative about lazy daughters-in-law who are a drain on young families. Non-migrant women I interviewed, on the contrary, were very willing to work but frustrated with the lack of opportunities in their villages. Many had young children and found amassing the capital to start a business difficult. Some helped with family enterprises or agricultural ventures but received no payment or recognition for their work. When tempers flared, they had to bear caustic remarks about "lazy people, who are only one more mouth to feed."

Manjula's case perhaps illustrates non-migrant women's dilemma best. She had a twoyear-old son, and when I visited her for the first time in 2007 I found that she had been far from lazy. Her garden was full of colorful anthuriums, orchids, and roses. When I selected some plants and insisted on paying, she accepted the money with both hands, saying this was the first time in her life she ever got paid. Selling flowers requires connections in Colombo, which Manjula and her family could not develop, and even in 2018 she only had few customers and they only bought one or two plants at a time. Manjula said she has to tolerate her in-laws' constant jibes about not being able to help her husband monetarily. In fact, her mother-in-law once told me that raising children these days is not the chore it was in the past and women should therefore find ways to help their men succeed. She added, "there are such talented women in this village - if this girl wants to learn from them." Later Manjula confided that she badly wanted to work in the FTZ, but her parents dissuaded her, claiming that her future in-laws would not respect her if she did so. Manjula found it ironic that her in-laws now wanted her to learn from 
[Type here]

former FTZ workers. This demonstrates the clash of competing common senses that her parents and in-laws hold, leaving Manjula to live her life at the intersection, daily making sense of these competing prescriptions for living.

All the villages I visited had several organizations providing micro-credit to women, and many non-migrant women were members. However, former FTZ workers usually dominated positions, such as chairperson, bank manager, and preschool teacher, at these organizations, and they were the most successful in obtaining loans and showing business success. One of the reasons for this was that the husbands of non-migrant women had poor confidence in their wives' ability to succeed and thus discouraged them from starting businesses. Most times these women were chosen as spouses due to their more sheltered lives as non-migrant women, and the poor confidence in their abilities stem from it. Manjula was thus prevented from investing in her flower business and instead obtained small loans for her family's needs, which her husband paid off when he could. In a way, monetary assistance alone would not have helped women like Manjula who did not have direct contacts with urban markets. This disparity in how some women were able to manipulate urban contacts and micro-credit opportunities demonstrates the role former workers' FTZ experience plays. Most of these non-migrant women's predicament exemplified the changing times where rural people are getting increasingly enamored by market relations and profits. Non-migrant women struggled to verbalize the deep frustrations they felt about being caught up between two competing prescriptions for being 'good women,' and at times responded by snide remarks on successful former workers" "men-like" behavior or ‘sullied' reputations.

\section{When Capital and Social Conformity Cannot Overcome Deeper Concerns}


[Type here]

While many former workers were successful in manipulating capital for economic and social gains, some find that neither astute capital management nor social conformity help in ameliorating family and community objections. In such instances they either choose or are forced to choose social relationships over economic activities. In one case, the woman achieved the approval of her parents-in-law only to be thwarted in her attempts at economic success by her jealous husband. In one case, a highly successful former worker had to curtail some of her entrepreneurial activities when her daughter married into a high status family which disapproved her engaging in physical labor while tending to her chicken farms.

Sometimes no amount of discipline and conformity can overcome deeper concerns about religion, nation, and corrupting urban influences. Anusha had to abandon a successful business raising pigs for meat when neighbors expressed concerns that she was bringing un-Buddhist activities to "a pure and moral Buddhist village." Anusha married her boyfriend and moved in with his parents. While at the FTZ, she learned that people raised pigs in their compounds for large meat companies. After her first baby, she, with the help of her Katunayake contacts, started a small pig farm in her back yard with 25 piglets. This was enormously successful and she earned Rs. 20,000 in net profit with the first batch. By this time, they were becoming aware of community displeasure, yet when the opportunity arose to raise 40 piglets for the same company she took on the challenge. This was when the community protests became official, with the village officer and the chief monk raising concerns. The mean looks and talk behind their backs were too much for the family, and Anusha soon abandoned the business. As another villager, a middle-aged man, had been raising pigs for village consumption on a very small scale (two or three at a time) for years, the antagonism against Anusha's larger business seems to point toward 
[Type here]

anxieties over the capitalist market's deeper penetration and how women's involvement in capital accumulation might change gender roles.

\section{FTZ Work and Entrepreneurial Success}

While it is beyond the purview of this article to determine whether a majority of former workers become successful entrepreneurs, the ethnographic data from the 37 villages clearly suggest that a majority of former workers were successful. Indeed, when village officers in the 37 villages were asked to put together lists of successful female entrepreneurs, the lists for 21 villages comprised entirely of FTZ workers. Additionally, former workers constitute over 75\% of all 37 lists. Five of the 37 former workers settled in their own villages with their spouse. With the ready support of their own mothers and relatives, these women had more space for economic success. Most of the former workers I studied (34) married up-to men whose families still had some land and, hence, status. Many such households did not need dowries for survival, which enabled the former workers to invest at least a part of it. Having husbands with stable incomes also gave them confidence to obtain microcredit, while access to affinal social capital helped build active relationships with village micro credit organizations.

What did not matter was whether the union was an arranged or love marriage. Most husbands (22), despite how the marriage came about, displayed varying levels of support for their wives' income-generating activities. Out of the 23 husbands I interviewed, 21 spoke very appreciatively of their wives' attempts to generate income, even if they had failed. Twenty husbands acknowledged that their wives' successes were connected to their FTZ employment, noting especially their savings, networks, and courageous attitudes. Mothers and fathers-in-law 
[Type here]

were also generally appreciative of what women achieved, but in day-to-day interactions some mothers-in-law resented daughters-in-law spending too much time outside the house.

While some studies show that women's increased economic power can lead to domestic violence, ${ }^{30}$ others note that whether the economic empowerment is protective against or increased domestic violence depend on context specific factors. ${ }^{31}$ Among the 37 interviewees and about 50 other former workers I spoke to, only two related physical violence against them, while 6 related sporadic verbal abuse. They all indicated in varied ways that their situation within marital relationships improved after their economic success. Even allowing for nondisclosed incidents, this is a positive picture. This results from the particular demographics of the former global workers in that they were well educated young women who even at the FTZ moved among different available identities to manage reputations. As women with a substantial 'FTZ dowry' they are able to marry into upwardly mobile young men from respectable yet mostly cash-strapped families. As demonstrated in this paper, former workers astutely manage any jealousy by performances of social conformity and symbolic nods to patriarchal authority. Overall, Sri Lankan villages appear to be grappling with the onslaught of market relations and the desire for more conventional economic and social hierarchies. Although an economically successful daughter in law helped families move up the village social ladder, activities associated with economic success also generate surreptitious talk about "not so respectable women who are visible in public spaces at times previously deemed inappropriate for young women." Affinal kin and neighborhood female support is thus crucial for young women to overcome these hurdles. Hence their continuing conformity to at least some forms of expected behavior.

\section{Conclusion}


[Type here]

Former workers' entrepreneurial efforts, at least at the outset, proclaim them to be neoliberal subjects who are self-motivated and concerned with economic gain and self-interest. The differing outcomes between former workers and non-migrant women's entrepreneurial efforts lie in the former workers' monetary capital and the sensibilities acquired and/or enhanced within the FTZ. Their success was not solely based on FTZ savings, knowledges and networks but also on how they combined and manipulated those sources of capital with what they have available within their villages: family social standing and cultural knowledges. Thus individual traits and talents also matter in finding success. Furthermore, success depends on how families and communities respond to their efforts. How they negotiate village social and economic lives also depend on a multitude of conditions unrelated to the FTZ. This noted, it is difficult to downplay how the FTZ interlude shaped how former workers negotiate newer forms of social and economic lives for themselves.

Rather than completely encroaching Sri Lanka's countryside, the neoliberal ethos is grappling with conventional ways of thinking and presenting rural communities an uncertain terrain that requires people to engage in a delicate dance of trade-offs. The former workers' engagement with village economic, social domains are initiating powerful processes of change. As they engage with these incoherent processes of change, former workers are rewriting the books on both who is an "entrepreneur" and "good wife and mother."

The former workers, as subcontracting owners/workers, are both collaborators and exploited workers of global production networks. The cascading system of global subcontracting produces hordes of home workers throughout the developing world, with the vast majority being women. This system advances the objective of ensuring low manufacturing costs in global production, because home workers typically make low wages, and receive no health 
[Type here]

and medical benefits. ${ }^{32}$ However, women like Hasini and Mayuri are also employers of part time female workers and thus part of a system that undermines the labor rights activism of the regular FTZ workforce. The more such flexible subcontracting operations there are, the more vulnerable the regular FTZ workers' position, as the subcontractors operate as 'just in time' picket jumpers from afar. Mezzadri and $\mathrm{Fan}^{33}$ focus on how incorporation of informal work in global commodity chains advance the capitalists' quest for more and more flexibility. Thus one can question whether the kind of economic empowerment I described earlier is really empowerment, as it contributes to increased vulnerability of global factory workers. However, similar to Mezzadri and Fan, I also hold that informal home work in villages allows workers to regain some degree of control over their wage and reproductive labor.

Moreover, the social changes they activate via these enterprises have set in motion a series of changes in social norms and hierarchies. Most of these changes are occurring in family, kinship and community realms and contribute to entrenched cultural tropes and sensibilities being re-articulated. At the same time, the women's membership in differently positioned families and communities significantly affect how such neoliberal ethos gets articulated. Thus neoliberalism has not become "hegemonic as a mode of discourse" 34 in the Sri Lankan countryside. Because while neoliberalism has encroached the common sense way village people understand the world, village people, former workers and non-migrant women alike continue to experience lives at the intersection of new and old ways of understanding the world.

\section{Bibliography}

Board of Investment of Sri Lanka. “Katunayake-General Information.” (2016) http://www.investsrilanka.com/free_trade_zones/katunayake. Retrieved 07/06/2018. 
[Type here]

Bolis, Mara and Christine Hughes. Women's Economic Empowerment and Domestic Violnece:

Links and Lesson for Practitioners Working with Intersectional Approaches. USA: Oxfam, 2015.

Brooks, David. "Psst! "Human Captial.” New York Times, November 13, Op Ed: A12. 2005.

Chari, Sharad. Fraternal Capital: Peasant-Workers, Self-Made Men, and Globalization in Provincial India. Stanford: Stanford University Press, 2008.

Christian, Alvin. Microfinace as a Determinant of Domestic Violence in Bangladesh: Who is at Risk?" CUNY Academic Works. http://academicworks.cuny.edu/cc_etds_theses/585, 2015. Dabindu Collective. Living for the Day: Contract Workers in Sri Lanka's Free Trade Zones. Nugegoda: Neo Graphic, 2017.

Dalal,Kaustuv, Dahlstrom, Orzan and Toomas Timpka. "Interactions between Microfinance Programmes and Non-economic Empowerment of Women Associated with Intimate Partner Violence in Bangladesh: A Cross-sectional Study.” BMJ Open 3 no.12 (2013). https://bmjopen.bmj.com/content/3/12/e002941.

Delaney, Annie, Rosaria Burchielli, and Tim Connor. "Positioning Women Homeworkers in a Global Footwear Production Network: How Can Homeworkers Improve Agency, Influence and Rlaim Rights? Journal of Industrial Relations (2015):

https://doi.org/10.1177/0022185615582237.

De Neve, Geert. "Entrapped Entrepreneurship: Labour Contractors in the South Indian Garment Industry." Modern Asian Studies 48, no. 05 (2014):1302-1333.

Fernandez-Kelly, Maria Patricia. For We Are Sold, I And My People. Albany: SUNY Press, 1983. 
[Type here]

Fevre, Ralph. Individualism and Inequality: The Future of Work and Politics. London: Edward Elgar, 2016.

Foucault, Michele. The Birth of Biopolitics: Lectures at the College de France, 1978-1979. New York: Palgrave, 2008.

Freeman, Carla. Entrepreneurial Selves: Neoliberal Respectability and the Making of a Caribbean Middle Class. Durham: Duke University Press, 2014.

Gibson-Graham, J.K. A Postcapitalist Politics. Minneapolis. University of Minnesota Press, 2006.

Gershon, Ilana. "Employing the CEO of Me, Inc.: US Corporate Hiring in a Neoliberal Age." American Ethnologist (2018) https://doi.org/10.1111/amet.12630.

Guganeshan, Mithula. 2017. "Easy Access To Credit Triggers Violence Against Women In Sri Lanka.” Colombo Telegraph, May 9. https://www.colombotelegraph.com/index.php/easyaccess-to-credit-triggers-violence-against-women-in-sri-lanka/.

Gunel, Gokce. "Producing Neoliberal Subjects: The Case of Koc University.” Berkley Journal of Sociology 53 (2009):4-25.

Islam, Saif. 2013. "Domestic Violence in Bangladesh: Blame it on Microfinance." The Guardian, September 11. https://www.theguardian.com/global-development-professionalsnetwork/2013/sep/11/microfinance-bangladesh-violence-against-women.

Harvey, David. A Brief History of Neoliberalism. Oxford: Oxford University Press, 2007.

Hewamanne, Sandya. "Crafting Social Change: Former Global Factory Workers Negotiating New Identities in Sri Lanka's Villages.” Identities (2017). DOI: 10.1080/1070289X.2017.1380942. 
[Type here]

Hewamanne, Sandya. "Duty Bound?: Militarization, Romances and New Spaces of Violence among Sri Lanka’s Free Trade Zone Garment Factory Workers.” Cultural Dynamics 21, no. 2 (2009):153-184.

Hewamanne, Sandya. "Sewing their way up the Social Ladder: Paths to Social Mobility and Empowerment among Sri Lanka's Global Factory Workers.” Third World Quarterly (2018). DOI: $10.1080 / 01436597.2018 .1458302$.

Hewamanne, Sandya. Sri Lanka's Global Factory Workers: (Un)Disciplined Desires and Sexual Struggles in a Post-Colonial Society. London: Routledge, 2016.

Hewamanne, Sandya. Stitching Identities in a Free Trade Zone: Gender and Politics in Sri Lanka. Philadelphia: University of Pennsylvania Press, 2008.

Karim, Lamia. Microfinance and Its Discontents: Women in Debt in Bangladesh. Minneapolis: University of Minnesota Press, 2011.

Khalid, Javeira and Choudhry, Misbah. "Violence and Economic Empowerment of Women in Pakistan: An Empirical Investigation.” Journal of Interpersonal Violence (2018). DOI:

\section{$10.1177 / 0886260518800318$.}

Lynch, Caitrin. Juki Girls, Good Girls: Gender and Cultural Politics in Sri Lanka's Global Garment Industry. Ithaca: Cornel University Press, 2007.

Madurawala, Sunimalee. 2018. "Economically Empowering Sri Lankan Women: One Strategy does not Fit All.” Daily Mirror, March 8. http://www.dailymirror.lk/article/Economicallyempowering-Sri-Lankan-women-One-strategy-does-not-fit-all-146907.html. Mas Holdings. "Women go Beyond Gallery.” n.d. Accessed February 2, 2018. http://www.masholdings.com/women-go-beyond.html\#women-go-beyond-gallery. 
[Type here]

Mezzadri, Alessandra. "Industrial Garment Clusters and CSR Norms: Incompatible Agendas at the bottom of the Garment Commodity Chain." Oxford Development Studies 42 (2014):238-258. Mezzadri, Alessandra and Sanjita Majumder. “The 'Afterlife' of Cheap Labour: Bangalore

Garment Workers from Factories to the Informal Economy.” Working Paper No: 12.18.1. FEDI: Female Employment \& Dynamics of Inequality Research Network, 2018.

Mezzadri, Alessandra and Lulu, Fan. 'Classes of Labour' at the Margins of Global Commodity Chains in India and China'. Development and Change 49, no. 4 (2018):1034-1063.

Mills, Mary Beth. Thai Women in the Global Labor Force: Consuming Desires: Contested Selves. New Brunswick: Rutgers University Press, 1999.

Mills, Mary Beth. “Gendered Morality Tales: Discourses of Gender, Labour, and Value in Globalising Asia.” Journal of Development Studies 53, no.3 (2018): 316-330.

Ngai, Pun. Made in China: Women Factory Workers in a Global Workplace. Durham: Duke University Press, 2005.

Ong, Aihwa. Spirits of Resistance and Capitalist Discipline: Factory Women in Malaysia. Albany: State University of New York Press, 1987.

Ong, Aihwa. "Neoliberalism as a Mobile Technology." Transactions of the Institute of British Geographers 32, no.1 (2007): 3-8.

Rose, Nicholas. The Powers of Freedom: Reframing Political. Cambridge: Cambridge University Press, 1999.

Salzinger, Leslie. Genders in Production: Making Workers in Mexico's Global Factories. Berkley: University of California Press, 2003. 
[Type here]

Todoli-Signes. Adrian. “The 'Gig Economy’: Employee, Self-employed or the Need for a Special Employment Regulation?" Transfer: European Review of Labour and Research 23, no.2 (2017): 193-205.

Vyas, Seema and Charlotte Watts. "How does Economic Empowerment Affect Women's Risk of Intimate Partner Vilence in Low and Middle Income Countries? A Systematic Review of Published Evidence.” Journal of International Development 21 (2009):577-602.

${ }^{1}$ Chari, Fraternal Capital.

${ }^{2}$ Mezzadri, "Industrial Garment Clusters.”

${ }^{3}$ De Neve, "Entrapped Entrepreneurship."

${ }^{4}$ Fernandez -Kelly, For We are Sold; Ong, Spirits of Resistance; Mills, Thai Women; Salzinger, Genders in Production; Pun, Made in China.

${ }^{5}$ Hewamanne, Sri Lanka's Global Factory Workers.

6 Dabindu, Living for the Day; Hewamanne, "Duty Bound?"; .Hewamanne, "Sewing their Way Up.”

${ }^{7}$ Hewamanne, Sri Lanka's Global Factory Workers; Hewamanne, "Crafting Social Change."

${ }^{8}$ Hewamanne, Stitching Identities; Sri Lanka's Global Factory Workers.

${ }^{9}$ Mas Holdings, "Women Go Beyond."

10 Todoli-Signes, "The 'Gig Economy."”

${ }^{11}$ Madurawala, "Economically Empowering." 
[Type here]

${ }^{12}$ Harvey, A Brief History, 2.

${ }^{13}$ Rose, The Powers of Freedom; Gunel, "Producing Neoliberal Subjects"; Fevre, Individualism and Inequality.

${ }^{14}$ Gershon, "Employing the CEO of Me."

${ }^{15}$ Harvey, A Brief History; Rose, The Powers of Freedom.

${ }^{16}$ Ong, "Neoliberalism as a Mobile Technology," 5

${ }^{17}$ Mills, Gendered Morality Tales.”

${ }^{18}$ Lynch, Juki Girls, Good Girls.

${ }^{19}$ Hewamanne, Stitching Identities.

${ }^{20}$ Freeman, Entrepreneurial Selves.

${ }^{21}$ Gibson-Graham, A Postcapitalist Politics.

${ }^{22}$ Foucault, The Birth of Biopolitics, 226-235.

${ }^{23}$ Brooks, "Psst! "Human Captial."

${ }^{24}$ These micro credit programs are run by local branch offices associated with international national organizations like CIDA, UNICEF, FORUT. Major state and private banks also provide micro credit to rural women. High interest, harassment, and court cases associated with defaulting are mostly associated with micro loans taken from private financial institutions such as Lanka Orient Leasing Company (LOLC).

${ }^{25}$ Karim, Microfinance and Its Discontents. Christian....

${ }^{26}$ Guganeshan, "Easy Access to Credit.”

${ }^{27}$ Christian, Microfinance as a Determinant; Islam, "Domestic Violence in Bangladesh."

${ }^{28}$ Mezzadri and Majumder, "The 'Afterlife' of Cheap Labour."

${ }^{29}$ Mezzadri and Majumder, "The 'Afterlife' of Cheap Labour." 
[Type here]

${ }^{30}$ Bolis and Hughes, Women's Economic Empowerment; Khalid and Chaudhry, "Violence and

Economic Empwoerment.”

${ }^{31}$ Vyas and Watts, "How does Economic Empowerment."

32 Delaney et al, "Positioning Women Homeworkers."

${ }^{33}$ Mezzadri and Fan, "Classes of Labour."

${ }^{34}$ Harvey, A Brief History, 3. 